\title{
A study on trade frictions of China's new energy auto in international marketing and the countermeasures
}

\author{
Lingzhi Zhao* \\ Changchun Institute of Technology, No.395 Kuanping Road, Chaoyang District of Changchun City, \\ Jilin Province, China
}

\begin{abstract}
Manifestations of China's new energy auto trade frictions are analyzed in this paper. The influence and causes of China's new energy auto trade frictions are explored. It included individualism versus collectivism, long-term orientation versus short-term orientation, masculinity versus femininity. Finally, the countermeasures of relieve auto trade frictions have been provided, such as strengthening international exchanges, cultivating international management talents, and enhancing the ability of managing the trade frictions in international marketing. The development of China's new energy vehicles to seek technological innovation in key fields like new energy vehicle batteries can be push forward. For Chinese auto companies, the investment should be reinforced and their independent innovation capabilities should be enhanced. Some suggestions for the sound development of China's new energy auto trade in the future have been provided in order to build brand-new harmonious international atmosphere,
\end{abstract}

Keywords: New energy auto; trade frictions; countermeasures

\section{Introduction}

As the two largest economies in the world, trade between China and the United States has continuously on the upward slide in recent years. There is a wide range of trade between the two countries. The United States is China's largest import and export trade partner in automobile trade. The trade between China and the United States is inseparable. As well, The United States is China's largest source of automobile imports, and China's largest export destination of spare parts is the United States (Robert, Z. Lawrence, 2018). Sino-US trade is interdependent. Trade friction between the two countries indicates that there is a trade surplus between China and the United States.

\section{Review of China's auto trade frictions}

After China's accession to the WTO, China's auto exports have grown rapidly, with 43,000

\footnotetext{
* Corresponding author: ky@ccit.edu.cn
} 
cars exported in 2003 and 173,000 in 2005, surpassing the import volume for the first time. In 2011, the highest growth rate had been achieved for China's automobile export since the financial crisis. The total export volume increased $49.99 \%$ year on year to 850,000 vehicles. The total export volume increased $56.82 \%$ year on year to more than 10 billion US dollars, up 53.33 times compared with 2001. China's Ministry of Commerce has decided to impose a "double anti" tariff on this type of car imported from the United States from December 15, 2011 to December 14, 2013. However, at the routine meeting of the WTO Dispute Settlement Body on October 23, 2012, the United States said that China's anti-dumping and countervailing investigations against its automobile industry had procedural and substantive defects and violated relevant WTO rules. However, our country has proved with real and reliable factual reports that the products involved in the dispute are indeed dumped and subsidized, causing serious losses to Chinese automobile enterprises, and has solemnly declared that China's "double-counter" measures are in conformity with WTO rules. Subsequently, the World Trade Organization set up an expert group to initiate an investigation, formally hearing the case of " United States - Definitive Anti-Dumping and Countervailing Duties on Certain Products from China ". On May 26, 2014, the WTO announced that China had won the case against the United States over a trade dispute over tariffs on imported U.S. cars. However, China has already indicated that it will stop levying double tax on American cars after the implementation expires on December 15, 2013. From the US special tire insurance case against China in 2009 to the Sino-US automobile trade dispute case in 2012 and the WTO ruling in 2014, the automobile trade friction between the two countries has been escalating(Anderson, 2009).

\section{Manifestations of China's auto trade frictions in international marketing}

\subsection{Case study}

The automobile industry is greatly struck by the escalating trade friction between China and the United States, and the areas in automobile component trade, vehicle trade and new energy automobile trade are covered in the automobile trade frictions.

\subsubsection{Trade friction of automotive component}

Sino-US trade friction of automotive components is mainly reflected in the field of tire trade. In 2007, an anti-dumping investigation on tires against China was conducted by the United States. In 2009, a notice to undertake a special insurance investigation on tires for passenger cars and light trucks in the United States was issued by the United States International Trade Commission. In 2013, a sunset review of China's off-the-road tires and conducted 333 investigations on six tire enterprises in China was launched by the United States. In 2014, the United States again carried out an "anti-dumping and countervailing" investigation on tires for passenger cars and light trucks in China. In 2016, the United Steelworkers Union filed a petition for a "anti-dumping and countervailing" investigation on tires for off-the-road tires in China.

\subsubsection{Anti-dumping investigation}

In 2016, the United Steelworkers Union filed a petition for a "anti-dumping and countervailing" investigation on tires for off-the-road tires in China. On January 23, 2017, DOC made the final ruling, with anti-dumping rates reaching $9 \%$ and $22.57 \%$, and anti- 
subsidy rates reaching 38.61\%, 52.04\% and 65.46\% (Samuel MazIsaac, 2020). On February 22, 2017, David S. Johnson, a republican member cast the last critical veto at the voting site of the ITC's industry damage vote on the final ruling of the car tire double reverse case, and the Chinese tire industry won by a 3:2 votes. This is the first time that China's tire industry has won a lawsuit against the U.S. anti-dumping and countervailing investigation and China appreciates that the U.S. International Trade Commission can respect facts and make public decisions. It is hoped that the two countries can continue dialogue and strengthen exchanges to achieve mutual benefits and win-win results.

\subsubsection{Trade friction of new energy vehicles}

On March 23, 2018, a memorandum was signed by Trump, American President. Based on the "301 investigation" report on China, tariffs and restrictions on products imported from China would be imposed, with the value of Chinese products involved in taxation reaching 60 billion U.S. dollars. New energy vehicles were included in these products. JAC(a brand of vehicles production) motors started export plan for new energy vehicles in 2013. For the first time, 2,000 new energy vehicles have stepped out of the country and entered the US market, though the factory's sales volume has been sluggish in recent years. For the typical brand of the production are new energy vehicles, trade friction has dealt a heavy blow to its sales. Any Ka buses have been exported to more than 60 countries and regions such as the United States. Affected by this, Any Ka coach shares fell by $9.94 \%$ on March 23. A negative impact of the survey have been revealed on the development of various industries in China. The development of economies of China and the United States will be hindered by the escalation of trade friction.

\subsection{The influence of auto trade friction}

Transmission system and engine parts are mainly factors which resulting in a trade deficit China's imports of parts from the United States. On the other hand, from the structural point of view, China's exports of automotive components are mainly low value-added products. The list of taxes is mainly for products with high added value. In the short term, it will have little impact on China's automotive components enterprises. But if Sino-US trade friction continues, it will bring many adverse effects on China's export of automotive components. In particular, it will take a great toll on parts companies that export to the United States but without overseas factories. New energy vehicles are also included in the U.S. tax collection list. If Sino-U.S. trade frictions are repeated, companies or enterprises that do more business with the U.S. in new energy vehicles will be affected first. Tesla's newly established business in China consists of technology development, technical service, technical consultation and technology transfer, covering electric vehicles and components, batteries, energy storage equipment and photovoltaic products. The company's main business includes wholesale, import and export, and related supporting services instead of vehicle manufacturing. This means Tesla will penetrate the Chinese market mainly through electric vehicle parts and technologies, which will affect the domestic new energy vehicle market and China's own brand of new energy vehicles. However, it will promote China's new energy vehicles to seek technological innovation in key fields like new energy vehicle batteries. Moreover, these trade frictions have also pushed China's new energy automobile enterprises to explore other international markets outside the United States.

\section{The causes of trade frictions of China's new energy auto}




\subsection{Individualism and collectivism}

On the other hand, the strong concept of individual independence makes it sometimes difficult for the U.S. decision-making authorities to clearly and comprehensively understand the interdependence between international trade and economic relations. Americans deem it unfair when their country has no advantage in auto trade. In contrast, for Chinese people who emphasize collectivism, individual will and emotion were often not the most important factors that determine the behavior. In China, sometimes one's own will and feelings may be ignored. Any behavior that may bring influence and consequence to others should be carefully considered. Noticeably, what is important is that China's collectivism is strikingly similar to the internal logic of mutual benefit and win-win outcomes in international trade. This has convinced China that the temporary deficit in the US auto trade does not necessarily mean hostility and conflict.

\subsection{Long-term orientation versus Short-term orientation}

This dimension reflects a nation's values of balancing long-term and short-term interests and is especially suitable to observe the cultural differences of the two countries. After launching the special protection investigation, the U.S. government announced that special duties would be imposed on the car tires of China-made passenger vehicles and light trucks by $55 \%, 45 \%$ and $35 \%$ for three consecutive years, which showed that government policies are often influenced by short-term orientations(Kim, S.H., 2014). The United States neglects the long-term shocks that can be brought about by trade protectionism and stresses too much the real economic and political benefits of the country in the short term. When short-term benefits are met in stages, the U.S. government will withdraw its troops. When the automobile trade is under new pressure, the United States will beat the drums again.

\subsection{Masculinity and femininity}

As one of the more intuitive links in economic development, automobile trade has become the forefront of this conflict. The masculinity culture of belligerence and rash advance has made the initiation of anti-dumping and countervailing investigations and special insurance investigations the way the United States deals with the imbalance of Sino-US automobile trade. However, China always embraces the femininity culture of gentleness and softness to control masculinity. Chinese traditional culture also advocates the concept of social harmony and the value of goodwill.

\section{The Countermeasures}

China-US auto trade friction will last for a long time, and this chapter will propose some countermeasures to ease the friction from the cross-cultural perspective and to enhance cultural exchanges between China and the United States.

\subsection{Cultivating international management talents}

On the one hand, different cultural factor should be considered in terms of cross-cultural management, and only when this new culture is rooted in all members of the enterprise, can the goal of cross-cultural management be truly accomplished. On the other hand, global enterprises should not neglect human management in cross-cultural management. To put it more specifically, not only the managers should have a deep understanding of the corporate 
culture of the parent company, but also the company should employ managers with cultural integration ability to shoulder responsibilities of cross-cultural management in foreign branches.

\subsection{Enhancing the ability of managing trade frictions}

Except strengthening cultural exchanges and nurturing international management talents, enhancing dispute management ability of China Association of Automobile Manufactures should also be placed on the agenda. As a permanent member of the World Organization of Automobile, China Association of Automobile Manufactures should conduct in-depth research on major problems of the industry, put forward measures and suggestions, and promote healthy and sustainable development of the industry. The association should also set up a multi-level working platform to improve the normal communication mechanisms such as industrial development forum and part development forum. And the China Automobile Association should give full play to its role as a bridge to communicate the demands of the industry to relevant government departments and offer corresponding policy suggestions.

\section{Conclusion}

As trade frictions of China's new energy auto are inevitable, international exchanges between China and other countries should be strengthened. China's foreign policies on peace, development and cooperation in the international arena of multilateral activities should be adopted, and the scope and space for foreign cultural work should be expanded. A large number of cross-cultural management talents should be trained. There is no doubt that Chinese enterprises need to cultivate management teams with cross-cultural communication competence to go global, which means that China needs to train international management talents. China should improve the coordination ability of China Association of Automobile Manufactures. A multi-level working platform to strengthen the normal communication mechanisms should be built. The importance of WTO dispute settlement mechanism China should be fully realize. In view of the aforementioned shortcomings, it is expected that further amendments can be made in future studies.

\section{Acknowledgement}

This research was financially supported by the Society and Science Research Project of Department of Education of Jilin Province in 2020 (120190064).

\section{References}

1. Anderson B, Lee H S., The US auto industry: historical background, trade policies, and new challenges[J].World Review of Entrepreneurship Management \& Sustainable Development, 286(2009)

2. Kim S H, Martin-Hermosillo M, Jia J. The U.S.-China Trade Friction: Causes and Proposed Solutions[J]. Journal of Applied Business \& Economics, 5,63-73(2014)

3. Robert, Z, Lawrence. Can the Trading System Survive US - China Trade Friction? [J]. China \& World Economy, 62(2018).

4. Samuel MacIsaac. Trade and conflict: trends in economic nationalism, unilateralism and protectionism[J]. Canadian Foreign Policy, 82(2020). 